\title{
Highly Regioselective and Stereoselective Biohydroxylations of Oxandrolone
}

\author{
Paulina Łyczko *(D), Anna Panek and Alina Świzdor *
}

\section{check for}

updates

Citation: Łyczko, P.; Panek, A.; Świzdor, A. Highly Regioselective and Stereoselective Biohydroxylations of Oxandrolone. Catalysts 2021, 11, 16. https: / /dx.doi.org/10.3390/catal 11010016

Received: 5 December 2020

Accepted: 23 December 2020

Published: 25 December 2020

Publisher's Note: MDPI stays neutral with regard to jurisdictional claims in published maps and institutional affiliations.

Copyright: $\odot 2020$ by the authors. Licensee MDPI, Basel, Switzerland. This article is an open access article distributed under the terms and conditions of the Creative Commons Attribution (CC BY) license (https: / / creativecommons.org/ licenses/by/4.0/).
Department of Chemistry, Wrocław University of Environmental and Life Sciences, 50-375 Wrocław, Poland; anna.panek@upwr.edu.pl

* Correspondence: paulina.lyczko@upwr.edu.pl (P.Ł.); alina.swizdor@upwr.edu.pl (A.Ś.)

\begin{abstract}
Microbially catalyzed reactions are a powerful and valuable tool for organic synthesis of many compounds with potential biological activity. Herein, we report efficient hydroxylations of the steroidal anabolic-androgenic lactone, oxandrolone, in the cultures of three strains of fungi, Fusarium culmorum, Mortierella isabellina, and Laetiporus sulphureus. These reactions resulted in the production of four metabolites identified as $12 \beta$-hydroxyoxandrolone (2), $9 \alpha$-hydroxyoxandrolone (3), $6 \alpha$-hydroxyoxandrolone (4), and 15 $\alpha$-hydroxyoxandrolone (5), the latter being a new compound. The high substrate conversion rates and the product yields achieved indicate that these strains offer a new way to generate steroidal hydroxylactones with potential pharmaceutical interest. The structures of the isolated derivatives were characterized on the basis of spectroscopic data. The effect of modification of the A-ring structure of the steroid by the lactone group on the selectivity of hydroxylation in cultures of the tested fungi is also discussed.
\end{abstract}

Keywords: biotransformation; oxandrolone; steroidal hydroxylactones; stereoselective hydroxylations; Fusarium culmorum; Mortierella isabellina; Umbelopsis isabellina; Laetiporus sulphureus

\section{Introduction}

The ability of microorganisms to transform organic compounds makes them a suitable instrument for obtaining valuable molecules that cannot be formed easily by traditional chemical methods. As they occur at neutral $\mathrm{pH}$ and ambient temperature, and do not require expensive and harmful chemicals, biocatalytic reactions are easy to carry out, cost-effective and safe for the environment. Most fungal strains contain cytochrome P450 monooxygenases, similar to those of mammals, so they can carry out regioselective and stereoselective hydroxylation of molecules, such as steroids, which may increase or modify their biological activity [1]. The presence of a hydroxyl group in organic compounds affects their polarity, toxicity, extraction from the cell, and translocation via the cell membranes, while creating possibilities for various subsequent structural modifications in the search for new substances with healing properties [1,2].

Microbial hydroxylations are used commercially for the production of steroidal drugs and to produce steroidal key intermediates for their synthesis. The $11 \alpha_{-}, 11 \beta-, 9 \alpha_{-}$, and $16 \alpha$-hydroxylations are utilized in the global manufacture of corticosteroids [2,3]. The introduction of a hydroxyl group at the $11 \alpha$-position of progesterone by Rhizopus nigricans decreased the number of chemical steps from 36 to 11 in cortisone synthesis from deoxycholic acid and caused a remarkable reduction in the price of the drug [4]. As another example, $11 \beta$-hydroxylation of cortexolone by Culvularia lunata is used to obtain hydrocortisone $[2,4,5]$, and $9 \alpha$-hydroxy steroids are intermediates for the production of more active $9 \alpha$-halogenated corticoids. The presence of a $16 \alpha$-hydroxyl group in halogen corticosteroids enables a reduction of the undesirable mineralocorticoid activity of these derivatives $[2,3,6]$. Steroid hydroxylations occurring in other sites, including the $7 \alpha-, 7 \beta-, 14 \alpha-$ and $15 \alpha$-positions, may have the potential for industrial operation. The $7 \alpha$-hydroxylation of cholesterol is essential for the production of bile acids, which have a 
variety of applications in the biomedical and pharmaceutical fields due to their peculiar physicochemical and biological properties [1,7]. Furthermore, 7-hydroxy derivatives of steroidal 5-en olefins, e.g., the widely available dietary supplement dehydroepiandrosterone (DHEA), exhibit several-fold higher immunoprotective and immunoregulatory properties than their precursors [8-10]. Other studies report that $14 \alpha$-hydroxylation is used in the synthesis of intermediates for the production of cardioactive steroids or inhibitors for breast cancer cells [1,2], and $15 \alpha$-hydroxylation is employed in the synthesis of contraceptives [2]. Although during systematic investigations it has been proved that, depending on the specificity of the given microorganism, every site in the steroid molecule is accessible for hydroxylation, current trends focus on the detection and isolation of strains with novel activity or a more efficient transformation capacity. Due to the nature of fungal hydroxylases and difficulties related to their isolation, purification and maintenance of catalytic activity, whole-cell transformation processes remain the method of choice for these studies.

In this study, as a continuation of the research on the transformation of androgenanabolic steroids, reactions of a steroidal lactone-oxandrolone (1) with three fungal species (Fusarium culmorum AM282, Mortierella isabellina AM212 (current name Umbelopsis isabellina [11]), and Laetiporus sulphureus AM498) were carried out. Fusarium culmorum and M. isabellina were previously known for their ability to metabolize steroidal compounds with different structures $[9,12-15]$.

Oxandrolone (17 $\beta$-hydroxy- $17 \alpha$-methyl-2-oxa- $5 \alpha$-androstan-3-one) is a widely available synthetic 2-oxa derivative of dihydrotestosterone with much lower androgenic activity than the parent compound. First synthesized in 1962, two years later it was introduced to the US market under the name Anavar ${ }^{\circledR}$ and was used to treat alcohol hepatitis, Turner syndrome and osteoporosis [16-18]. Nowadays, oxandrolone is also used in the treatment of genetic growth disorders, people with significant physical trauma, particularly burns, and patients with AIDS who have suffered a large weight loss [19]. The use of oxandrolone significantly decreases wound healing time and increases weight re-gain, which directly translates into reducing the length of hospital stay [20]. As this compound does not significantly affect testosterone production and does not aromatize, it is considered the safest of all steroids [21]. Regarding oxandrolone's accessibility, anabolic activity and relatively weak side-effects, it is also one of the most often abused drugs in sport [22,23]. It should be noted that, according to the regulations of the World Anti-Doping Agency, the administration of oxandrolone is prohibited [24]. Among the known metabolites of oxandrolone identified in humans are its epimeric forms-epioxandrolone, 18-nor-oxandrolone, and 16 $\alpha$-, and $16 \beta-$ hydroxyoxandrolone [25]. Additionally, $17 \alpha$ - and $17 \beta$-hydroxymethyl-18-nor-oxandrolone have been detected as long-term metabolites [22].

Unlike other widely tested anabolic $17 \alpha$-alkylated androstanes, i.e., $17 \alpha$-methyltestosterone $[26,27]$, so far only a few studies concerning oxandrolone's bioconversion have been carried out. That substrate underwent $11 \alpha-, 6 \alpha$ - and $9 \alpha$-hydroxlation with Rhizopus stolonifer [21], and 12 $\beta$-hydroxylation with Cunninghamella blakesleeana [28]; however, the final yield of synthesized products was quite low $(0.8-24 \%)$. Only $11 \alpha$-hydroxyoxandrolone was synthesized with a $24 \%$ yield [21]. The mixture of four other oxygenated metabolites, namely, $11 \beta$-hydroxyoxandrolone (2.8\%); $5 \alpha, 11 \beta$-dihydroxyoxandrolone $(0.9 \%), 11 \beta, 20$ dihydroxyoxandrolone $(2.3 \%)$, and $17 \beta$-hydroxy- $17 \alpha$-methyl-2-oxa- $5 \alpha$-androstan-3,11dione $(1.4 \%)$, was obtained after incubation of that steroid in Macrophomina phaseolina culture [28].

Here, we present the results of an effective transformation of oxandrolone (1) to the known derivatives $12 \beta$ - (2), $9 \alpha$ - (3), and $6 \alpha$-hydroxyoxandrolone (4), and to the new compound-15 $\alpha$-hydroxyoxandrolone (5). The effect of the modification of the A-ring structure of the steroid by the lactone group on the selectivity of hydroxylation in cultures of the tested fungi is also discussed. 


\section{Results and Discussion}

Our results indicated that F. culmorum AM282, M. isabellina AM212 and L. sulphureus AM498 were able to convert oxandrolone (1) into its polar metabolites. The time-dependent progress of the transformations is compiled in Table 1. The structures of the obtained derivatives were established by spectroscopic methods by comparison of the characteristic shift values of selected diagnostic signals of products and the starting compound. The stereochemistry of the hydroxyl group was deduced on the basis of NOESY experiments.

The bioconversion of oxandrolone (1) with F. culmorum yielded only one main metabolite (Figure 1), which was obtained with a yield of $62 \% \mathrm{~mol}$. (69\% determined by GC analysis, see Table 1).
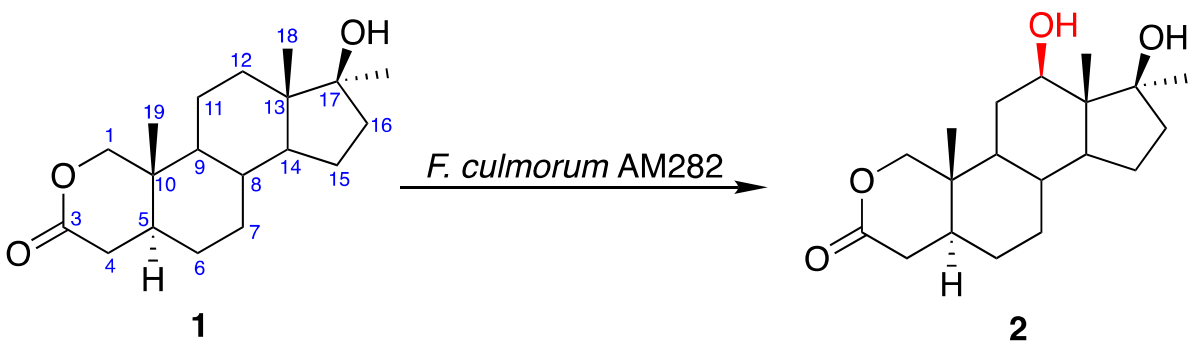

Figure 1. Transformation of oxandrolone (1) in the culture of Fusarium culmorum AM282.

Table 1. Compositions of crude extracts obtained in transformations of oxandrolone (1).

\begin{tabular}{|c|c|c|c|c|c|c|c|}
\hline \multirow{3}{*}{ Strain } & \multirow{3}{*}{$\begin{array}{c}\text { Compounds Present in the } \\
\text { Mixture }\end{array}$} & \multirow{3}{*}{$R_{t}$ (min.) } & \multicolumn{5}{|c|}{$\begin{array}{c}\text { Time of Transformation } \\
\text { (Days) }\end{array}$} \\
\hline & & & 1 & 3 & 5 & 7 & 10 \\
\hline & & & \multicolumn{5}{|c|}{$(\%)^{a}$} \\
\hline \multirow{2}{*}{$\begin{array}{c}\text { Fusarium culmorum } \\
\text { AM282 }\end{array}$} & Oxandrolone (1) & 7.14 & 84 & 55 & 26 & 22 & - \\
\hline & $12 \beta$-Hydroxyoxandrolone (2) & 10.06 & 16 & 38 & 66 & 69 & - \\
\hline \multirow{2}{*}{$\begin{array}{c}\text { Mortierella isabellina } \\
\text { AM212 }\end{array}$} & Oxandrolone (1) & 7.14 & 90 & 40 & 19 & - & - \\
\hline & $9 \alpha$-Hydroxyoxandrolone (3) & 9.15 & 10 & 48 & 69 & 80 & 78 \\
\hline \multirow{3}{*}{$\begin{array}{c}\text { Laetiporus sulphureus } \\
\text { AM498 }\end{array}$} & Oxandrolone (1) & 7.14 & 93 & 82 & 48 & 23 & - \\
\hline & 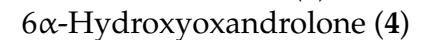 & 10.24 & - & - & 8 & 12 & 18 \\
\hline & $15 \alpha$-Hydroxyoxandrolone (5) & 9.83 & 7 & 15 & 39 & 61 & 76 \\
\hline
\end{tabular}

\footnotetext{
${ }^{a}$ Determined by GC analysis.
}

Mass spectrometry (MS) data of metabolite 2 revealed an $[\mathrm{M}]^{+}$at $\mathrm{m} / \mathrm{z} 323.2\left(\mathrm{C}_{19} \mathrm{H}_{30} \mathrm{O}_{4}\right)$, reflecting the additional $\mathrm{OH}$ group in the molecule. The ${ }^{1} \mathrm{H}-\mathrm{NMR}$ spectrum showed a new downfield methine proton signal at $\delta_{\mathrm{H}} 3.73-3.76 \mathrm{ppm}$, geminal to the hydroxyl group. In comparison to the spectrum of the substrate, the C-18 methyl signal of 2 demonstrated a downfield shift $(\Delta 0.07 \mathrm{ppm})$, suggesting that hydroxylation had occurred at the $12 \beta$ position. The appearance of a new methine carbon signal at $\delta_{C} 73.1 \mathrm{ppm}$ in the ${ }^{13} \mathrm{C}$ NMR spectrum, in combination with the downfield shifts of C-11 $(\Delta 10.9 \mathrm{ppm})$ and C-13 $(\Delta 4.1 \mathrm{ppm})$, and upfield shift of $\mathrm{C}-18(\Delta 5.5 \mathrm{ppm})$ when compared to the spectrum of 1 , was an important confirmation of $12 \beta$-hydroxylation. Additionally, the NOESY spectrum showed correlations between $12 \alpha-\mathrm{H}$ and $9 \alpha-\left(\delta_{\mathrm{H}} 0.90 \mathrm{ppm}\right), 14 \alpha-\left(\delta_{\mathrm{H}} 1.18 \mathrm{ppm}\right)$ proton, and $\mathrm{C}-17 \alpha\left(\delta_{\mathrm{H}} 1.35 \mathrm{ppm}\right)$ methyl group signals. Thus, product 2 was identified as $12 \beta$-hydroxy-oxandrolone. Its NMR data were comparable with those reported in the literature [28]. The effective introduction of $12 \beta-\mathrm{OH}$ group into the structure of $17 \alpha-$ alkylated androstanes by F. culmorum was not surprising. Although this strain converts C19 3-oxo-4-ene and 3 $\beta$-hydroxy- $5 \alpha$-saturated steroids to a mixture of their $6 \beta$ - and $15 \alpha-$ hydroxy derivatives [13-15,29], in the presence of an alkyl substituent at the $17 \alpha$-position, which is a drawback for $1-3$ cis hydroxylation at the $15 \alpha$-position, the reaction occurs 
at position $12 \beta$, which is its equivalent in enzyme-substrate complexes [2]. Thus, after transformation of $17 \alpha$-methyltestosterone in F. culmorum AM282 culture, the mixture of $6 \beta-$,

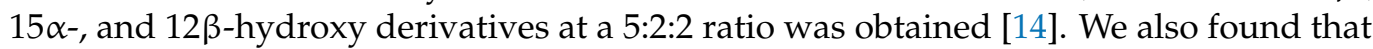
the modification of the ring A of steroids and replacement of 3-oxo-4-ene group with an unusual $\delta$ lactone moiety makes such orientation of the substrate in the complex with the enzyme, that $12 \beta$-hydroxylation occurs. [2]. 12ß-hydroxy-oxandrolone (2) was previously synthesized after 18 days of the transformation of $\mathbf{1}$ using Cunninghamella blakesleeana strain but it was isolated with only a $0.8 \%$ yield [28].

After seven days of incubation of oxandrolone (1) with M. isabellina AM212, three potential products were detected in the post-transformation extracts, but only one metabolite, 3 ( $80 \%$ based on GC analysis, see Table 1), was present in sufficient quantity for characterization (Figure 2).
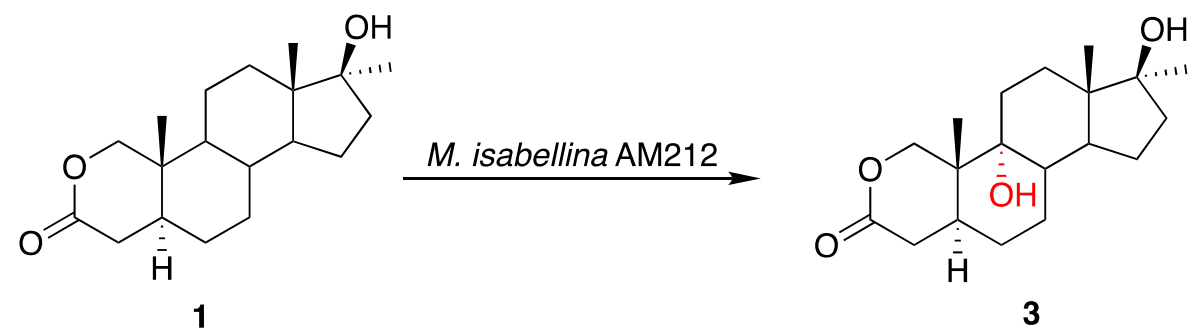

Figure 2. Transformation of oxandrolone (1) in the culture of Mortierella isabellina AM212.

The MS data of metabolite 3 exhibited an $[\mathrm{M}]^{+}$at $\mathrm{m} / \mathrm{z} 323.2$, which implied the incorporation of an oxygen atom to the substrate. In the ${ }^{1} \mathrm{H}$ NMR spectrum of 3 , the $\mathrm{CHOH}$ signal was absent. The signal of $\mathrm{OH}$-bearing quaternary carbon at $\delta_{\mathrm{C}} 74.2 \mathrm{ppm}$, the downfield shift of signals $C-10(\Delta 4.4 \mathrm{ppm}), \mathrm{C}-11(\Delta 2.1 \mathrm{ppm})$, and $\mathrm{C}-8(\Delta 2.7 \mathrm{ppm})$, and the $\gamma$-gauche upfield shifts of C-1 $(\Delta 4.4 \mathrm{ppm}), \mathrm{C}-5(\Delta 8.1 \mathrm{ppm}), \mathrm{C}-7(\Delta 3.5 \mathrm{ppm})$, C-12 $(\Delta 4.1 \mathrm{ppm})$, and C-14 $(\Delta 6.8 \mathrm{ppm})$ signals in comparison with the spectrum of metabolite 1 indicated that $9 \alpha$-hydroxylation had occurred. The proposed structure, $9 \alpha$ hydroxy-oxandrolone (3), was supported by the downfield shift of C-19 methyl signal by $0.10 \mathrm{ppm}$ with respect to the substrate. The spectroscopic data of this metabolite were consistent with those described in the literature [21] and $9 \alpha$-hydroxyoxandrolone (3) was previously reported as one of three products of a transformation using Rhizopus stolonifer with an isolated yield of $8 \%$ after 10 days of cultivation [21]. In the current study with $M$. isabellina AM212, the yield was improved to $71 \%$. In comparison to the transformation of epiandrosterone ( $3 \beta$-hydroxy- $5 \alpha$-androstan-17-one) by $M$. isabellina, which resulted in a mixture of $7 \alpha-, 9 \alpha-$, and $11 \alpha$-hydroxy derivatives [9], there is another example that the introduction of a lactone moiety into the A-ring of $5 \alpha$-saturated substrate enhances the regioselectivity of the hydroxylation.

Two others metabolites (4 and 5 at a 1:4.2 ratio) were detected after ten days of incubation of 1 with Laetiporus sulphureus AM498 (Table 1, Figure 3).

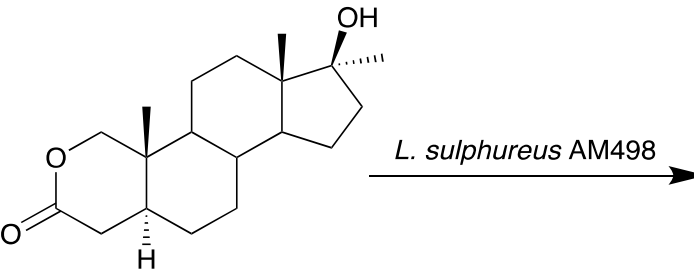

1

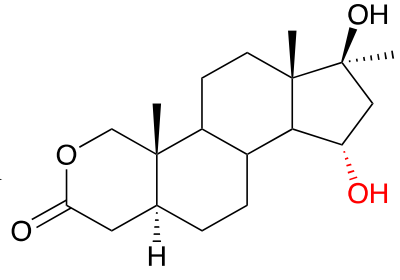

5<smiles>C[C@]1(O)CCC2C3C[C@H](O)[C@@H]4CC(=O)OC[C@]4(C)C3CC[C@]21C</smiles>

4

Figure 3. Transformation of oxandrolone (1) in the culture of Laetiporus sulphureus AM498. 
The MS spectra of both metabolites showed an $[\mathrm{M}]^{+}$at $\mathrm{m} / \mathrm{z}$ 323.2, corresponding to the formula $\mathrm{C}_{19} \mathrm{H}_{30} \mathrm{O}_{4}$ and indicating the incorporation of an oxygen atom into the structure of the substrate. The ${ }^{1} \mathrm{H}$ NMR spectrum of the less polar product revealed a new broad signal at $\delta_{\mathrm{H}} 3.45-3.49 \mathrm{ppm}$ suggesting hydroxylation at an equatorial proton. The significant shift of the 4-H signals (by $0.46 \mathrm{ppm}$ and $0.12 \mathrm{ppm}$ ) and lack of a shift of both the methyl signals pointed towards substitution at $6 \alpha-\mathrm{H}$. The appearance of a new methine carbon signal at $\delta_{C} 69.8 \mathrm{ppm}$, in combination with the downfield shift of the C-5 $(\Delta 6.7 \mathrm{ppm})$ and $C-7(\Delta 10.0 \mathrm{ppm})$, and $\gamma$-carbon upfield signal shift of $C-4(\Delta 3.1 \mathrm{ppm})$ and C-8 $(\Delta 0.9 \mathrm{ppm})$ confirmed $6 \alpha$-hydroxylation. Additionally, the NOESY spectrum showed a correlation between $6 \beta-\mathrm{H}$ and $4 \beta-(\delta \mathrm{H} 2.34 \mathrm{ppm}), 8 \beta(\delta \mathrm{H} 1.61 \mathrm{ppm})$ proton, and $\mathrm{C}-19$ $(\delta \mathrm{H} 1.02 \mathrm{ppm})$ methyl signals. These observations fully supported the structure of 4 as $6 \alpha$-hydroxyoxandrolone and were consistent with the spectroscopic data available in the literature [21]. It was previously reported that $6 \alpha$-hydroxyoxandrolone (4) was one of three metabolites obtained after 10 days transformation of $\mathbf{1}$ by Rhizopus stolonifer with a yield of $5 \%$ [21]. The ${ }^{1} \mathrm{H}$ NMR spectrum of the main reaction product, metabolite 5, showed a new broad hydroxyl-bearing methine proton signal at $\delta_{\mathrm{H}} 4.07 \mathrm{ppm}$. The characteristic shape and multiplicity of this signal (td, $J=3.4 \mathrm{~Hz} ; J=9.3 \mathrm{~Hz}$ ) suggested $15 \alpha$-hydroxylation. This was supported by an oxygen-bearing methine carbon signal at $\delta_{\mathrm{C}} 72.3 \mathrm{ppm}$, downfield shifts of the $\beta$-carbons $C-14(\Delta 7.7 \mathrm{ppm})$ and $\mathrm{C}-16(\Delta 11.6 \mathrm{ppm})$, and $\gamma$-carbon upfield signal shifts of $C-8(\Delta 0.5 \mathrm{ppm})$ and $\mathrm{C}-17(\Delta 2.5 \mathrm{ppm})$. Further supporting evidence of the stereochemistry of the new hydroxyl group was provided by NOESY spectrum analysis, in which the correlation signals between $15 \beta-\mathrm{H}$ and $\mathrm{H}-8\left(\delta_{\mathrm{H}} 1.68 \mathrm{ppm}\right)$, and $\mathrm{H}-16\left(\delta_{\mathrm{H}} 2.42\right.$ ppm) and C-18 methyl ( $\delta_{\mathrm{H}} 0.87 \mathrm{ppm}$ ) signals were visible (Table 2 and Figure 4$)$. These results confirmed the identification of 5 as $15 \alpha$-hydroxyoxandrolone. This compound is a new derivative of oxandrolone.

Table 2. Spectroscopic data of $15 \alpha$-hydroxyoxandrolone (5) *.

\begin{tabular}{|c|c|c|c|c|}
\hline Position & $\delta_{\mathrm{C}}$ & Type & $\delta_{\mathrm{H}}$, Multiplicity $(J$ in $\mathrm{Hz})$ & $\operatorname{NOESY}(\mathbf{H} \rightarrow \mathbf{H})^{a}$ \\
\hline $1 \alpha$ & \multirow{2}{*}{80.9} & \multirow{2}{*}{$\mathrm{CH}_{2}$} & $3.93, \mathrm{~d}(10.7)$ & 5,9 \\
\hline $1 \beta$ & & & 4.22, d (10.7) & 11,19 \\
\hline 3 & 170.4, & $\mathrm{C}$ & $x^{2}$ & - \\
\hline $4 \alpha$ & \multirow{2}{*}{ 33.7, } & \multirow{2}{*}{$\mathrm{CH}_{2}$} & $2.53, \mathrm{dd}(5.9 ; 18.8)$ & 6 \\
\hline $4 \beta$ & & & $2.22, \mathrm{dd}(13.0 ; 18.8)$ & $6,8,19$ \\
\hline 5 & 40.2 & $\mathrm{CH}$ & $1.72, \mathrm{~m}$ & $1,7,9$ \\
\hline $6 \alpha$ & \multirow{2}{*}{ 27.0, } & \multirow{2}{*}{$\mathrm{CH}_{2}$} & $1.51, \mathrm{~m}$ & 4 \\
\hline $6 \beta$ & & & $1.21^{\mathrm{b}}, \mathrm{m}$ & $4,8,19$ \\
\hline $7 \alpha$ & \multirow{2}{*}{ 31.3, } & \multirow{2}{*}{$\mathrm{CH}_{2}$} & $1.14, \mathrm{~m}$ & $5,9,14$ \\
\hline $7 \beta$ & & & $2.02, \mathrm{dm}$ & $6,8,15$ \\
\hline 8 & 35.1, & $\mathrm{CH}$ & $1.68, \mathrm{~m}$ & $6,11,18,19$ \\
\hline 9 & 49.5, & $\mathrm{CH}$ & $0.85, \mathrm{~m}$ & $1,5,7,12,14$ \\
\hline 10 & 34.7 & $\mathrm{C}$ & - & - \\
\hline $11 \alpha$ & \multirow[b]{2}{*}{20.8} & \multirow{2}{*}{$\mathrm{CH}_{2}$} & $1.46^{\mathrm{c}}, \mathrm{m}$ & 9 \\
\hline $11 \beta$ & & & $1.46^{\mathrm{c}}, \mathrm{dm}$ & $8,18,19$ \\
\hline $12 \alpha$ & \multirow{2}{*}{31.2} & \multirow{2}{*}{$\mathrm{CH}_{2}$} & $1.51, \mathrm{dm}$ & $9,14,20$ \\
\hline $12 \beta$ & & & $1.37, \mathrm{~m}$ & 11,18 \\
\hline 13 & 46.5, & C & - & - \\
\hline 14 & 57.9 & $\mathrm{CH}$ & $1.24^{b}, \mathrm{~m}$ & $9,12,20$ \\
\hline 15 & 72.3, & $\mathrm{CH}$ & $4.07(\mathrm{td}, 3.4 ; 9.3)$ & $7,8,11,16,18$ \\
\hline $16 \alpha$ & \multirow{2}{*}{50.3} & \multirow{2}{*}{$\mathrm{CH}_{2}$} & $1,64, \mathrm{dd}(3.4 ; 14.6)$ & 14,20 \\
\hline $16 \beta$ & & & $2.42, \mathrm{dd}(9.7 ; 14.6)$ & $8,15,18$ \\
\hline 17 & 79.1, & C & - & - \\
\hline 18 & 15.4 & $\mathrm{CH}_{3}$ & $0.87, \mathrm{~s}$ & $8,11,19$ \\
\hline 19 & 10.2, & $\mathrm{CH}_{3}$ & $1.02, \mathrm{~s}$ & $1,4,6,8,11$ \\
\hline 20 & 26.1, & $\mathrm{CH}_{3}$ & $1.35, \mathrm{~s}$ & $12,14,16$ \\
\hline
\end{tabular}

* $600 \mathrm{MHz}$ for ${ }^{1} \mathrm{H}$ NMR and $151 \mathrm{MHz}$ for ${ }^{13} \mathrm{C}$ NMR. ${ }^{\text {(a) }}$ NOESY correlations are from the stated proton to the indicated proton(s). ${ }^{(b, c)}$ Signals are interchangeable. 


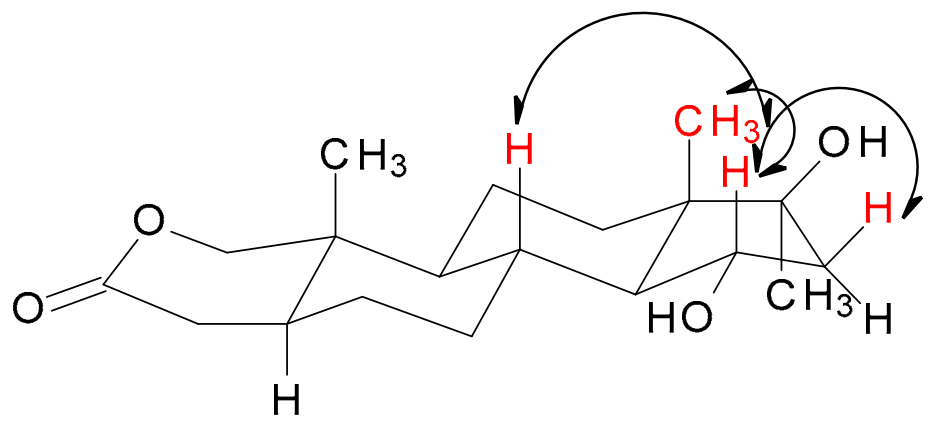

Figure 4. Key NOESY correlations for 15 $\alpha$-hydroxyoxandrolone (5).

To the best of our knowledge, this is the first report confirming $15 \alpha$-hydroxylation of oxandrolone by fungi. The use of L. sulphureus AM498 allowed us to obtain this hydroxylactone with a high yield $(70 \%$ mol.). Moreover, the use of mycelium of this edible polypore in the transformation of steroids compounds is described here for the first time.

\section{Materials and Methods}

\subsection{Substrate and Microorganisms}

The substrate oxandrolone (1) was purchased from Biosynth Carbosynth ${ }^{\circledR}$ (Berkshire, United Kingdom). The fungal strains Fusarium culmorum AM282, Mortierella isabellina AM212 and Laetiporus sulphureus AM498 were obtained from the collection of the Department of Pharmaceutical Biology and Botany of the Wrocław Medical University, Wrocław, Poland. Fungi were maintained on Sabouraud $4 \%$ dextrose agar slopes and freshly subcultured before use in the transformation experiments.

\subsection{Conditions of Cultivation and Transformation}

All strains were incubated in $300 \mathrm{~mL}$ Erlenmeyer flasks with $100 \mathrm{~mL}$ of a medium composed of $3 \%$ of glucose and $1 \%$ of proteose peptone (Biocorp, Warsaw Poland). Fungi were grown at $26^{\circ} \mathrm{C}$ on a rotary shaker $(130 \mathrm{rpm})$. After a specified time of cultivation that depended on the growth rate of the strain (2 days for Laetiporus sulphureus AM498 and Fusarium culmorum AM282, 3 days for Mortierella isabellina AM212), $0.06 \mathrm{~g}$ of substrate $\mathbf{1}$ in the form of an acetone suspension was equally distributed among three flasks with fungal cultures (final concentration $0.2 \mathrm{gl}^{-1}$ ). Transformations were carried out under the same conditions until the substrate was metabolized. To study the time-dependent progress of the bioconversion, $5 \mathrm{~mL}$ samples of the transformation medium were taken out at regular intervals $(48 \mathrm{~h})$ from the reaction flasks and processed as described in Section 3.3.

\subsection{Isolation and Identification of Products}

After transformations were performed, the mixture was extracted three times with chloroform $(3 \times 100 \mathrm{~mL})$. The organic extract was dried over anhydrous magnesium sulphate, concentrated in vacuo and analyzed by TLC and GC. Merck Silica gel $60 \mathrm{~F}_{254}$ plates and eluent chloroform/methanol $(70: 6 \mathrm{v} / \mathrm{v})$ were used for TLC analysis. To detect the steroids, the TLC plates were sprayed with a methanol/concentrated sulfuric acid $(1: 1 \mathrm{v} / \mathrm{v})$ mixture, heated at $120^{\circ} \mathrm{C}$ until the colors developed, and observed under UV light $(254 \mathrm{~nm})$. GC analysis was performed on a Hewlett Packard 5890 Series II GC instrument (FID, carrier gas $\mathrm{H}_{2}$ ) with the DB-5MS capillary column $(30 \mathrm{~m} \times 0.32 \mathrm{~mm}$, film $0.25 \mu \mathrm{m}$; Agilent Technologies, Inc., Warsaw, Poland). The temperature program for the GC analysis was as follows: $220^{\circ} \mathrm{C}$ for $1 \mathrm{~min}$ increasing by increments of $4{ }^{\circ} \mathrm{C} / \mathrm{min}$ to $270{ }^{\circ} \mathrm{C}$, then at a gradient of $30{ }^{\circ} \mathrm{C} / \mathrm{min}$ to $300{ }^{\circ} \mathrm{C}$, held at $300{ }^{\circ} \mathrm{C}$ for $3 \mathrm{~min}$; the injector and detector temperature was taken at $300^{\circ} \mathrm{C}$. MS analysis was performed on Varian CP-3800/Saturn 2000 apparatus (Varian, Walnut Creek, CA, USA) with a Zebron ZB-5 MSI $(30 \mathrm{~m} \times 0.25 \mathrm{~mm} \times 0.25 \mu \mathrm{m}$ ) column (Phenomenex, Torrance, CA, USA). Temperature conditions were as follows: $220^{\circ} \mathrm{C}$ for $1 \mathrm{~min}$, increasing by $5{ }^{\circ} \mathrm{C} / \mathrm{min}$ to $300{ }^{\circ} \mathrm{C}$, held at 
$300{ }^{\circ} \mathrm{C}$ for $7 \mathrm{~min}$. The injector temperature was $270{ }^{\circ} \mathrm{C}$ and the detector temperature was $220^{\circ} \mathrm{C}$. Biotransformation products were separated by column chromatography using Merck Silica gel $60(0.040-0.063 \mathrm{~mm})$ with chloroform/methanol $(70: 6 \mathrm{v} / \mathrm{v})$ as eluent. After evaporation of the eluent, the separated metabolites were weighed. The products' structures were defined in accordance with ${ }^{1} \mathrm{H}$ NMR and ${ }^{13} \mathrm{C}$ NMR analysis. The spectra were recorded on a Bruker Avance ${ }^{\mathrm{TM}} 600 \mathrm{MHz}$ spectrometer in $\mathrm{CDCl}_{3}$. Jasco P-2000 digital polarimeter (the version with an iRM controller, Mary's Court, Easton, MD, USA) was used to measure optical rotation. Melting points (uncorrected) were determined on the Boetius apparatus.

\subsection{Transformations and Spectroscopic Data of the Isolated Metabolites \\ 3.4.1. Transformation with Fusarium culmorum}

The seven day transformation process of oxandrolone (1) with F. culmorum AM282 resulted in a mycelial and broth extract, which was chromatographed on silica gel. Elution with methanol in chloroform yielded untransformed oxandrolone (1) (11 mg, 18\%mol.), and 12 $\beta$-hydroxyoxandrolone (2) (39 mg, 62\% mol.). Compound 2 was as follows: white plates, mp $190-193{ }^{\circ} \mathrm{C},[\alpha]_{\mathrm{D}}^{20}=-49\left(\mathrm{c} 0.02, \mathrm{CHCl}_{3}\right)\left(\right.$ lit.: $\left.\mathrm{mp} 195-196^{\circ} \mathrm{C}\right),[\alpha]_{\mathrm{D}}^{25}=-55(c 0.01$, $\mathrm{MeOH}$ ) [28]. EI-MS m/z 323.2 [M] $^{+}$(6), 307.3 (5), 286.2 (60), 246.5 (100), 43.1 (57). ${ }^{1} \mathrm{H}$ NMR $\left(\mathrm{CDCl}_{3}, 600 \mathrm{MHz}\right) \delta(\mathrm{ppm}): 0.90(\mathrm{~m}, 1 \mathrm{H}, 9-\mathrm{H}), 0.93(\mathrm{~s}, 3 \mathrm{H}, 18-\mathrm{H}), 1.02(\mathrm{~s}, 3 \mathrm{H}, 19-\mathrm{H}), 1.18(\mathrm{~m}$, $1 \mathrm{H}, 14-\mathrm{H}), 1.21(\mathrm{~m}, 1 \mathrm{H}, 6 \alpha-\mathrm{H}), 1.32(\mathrm{~m}, 1 \mathrm{H}, 11 \alpha-\mathrm{H}), 1.35(\mathrm{~s}, 3 \mathrm{H}, 20-\mathrm{H}), 1.41(\mathrm{~m}, 1 \mathrm{H}, 15 \beta-\mathrm{H})$, $1.43(\mathrm{~m}, 1 \mathrm{H}, 8-\mathrm{H}), 1.44(\mathrm{~m}, 1 \mathrm{H}, 11 \beta-\mathrm{H}), 1.48(\mathrm{~m}, 1 \mathrm{H}, 7 \beta-\mathrm{H}), 1.49(\mathrm{~m}, 1 \mathrm{H}, 6 \beta \mathrm{H}), 1.63(\mathrm{~m}, 1 \mathrm{H}$, $15 \alpha-\mathrm{H}), 1.68(\mathrm{~m}, 1 \mathrm{H}, 16 \beta-\mathrm{H}), 1.72(\mathrm{~m}, 1 \mathrm{H}, 7 \alpha-\mathrm{H}), 1.76(\mathrm{~m}, 1 \mathrm{H}, 5-\mathrm{H}), 1.85(\mathrm{~m}, 1 \mathrm{H}, 16 \alpha-\mathrm{H})$, $2.23(\mathrm{dd}, J=13.1 \mathrm{~Hz}, J=18.7 \mathrm{~Hz}, 1 \mathrm{H}, 4 \beta-\mathrm{H}), 2.53(\mathrm{dd}, J=5.8 \mathrm{~Hz}, J=18.6 \mathrm{~Hz}, 1 \mathrm{H}, 4 \alpha-\mathrm{H})$, 3.73-3.76 (m, 1H, 12 $\alpha-\mathrm{H}), 3.92(\mathrm{~d}, J=10.7 \mathrm{~Hz}, 1 \mathrm{H}, 1 \alpha-\mathrm{H}), 4.21(\mathrm{~d}, J=10.7 \mathrm{~Hz}, 1 \mathrm{H}, 1 \beta-\mathrm{H})$; ${ }^{13} \mathrm{C} \mathrm{NMR}\left(\mathrm{CDCl}_{3}, 151 \mathrm{MHz}\right) \delta$ (ppm): 8.4 (C-18), 10.1 (C-19), 23.0 (C-15), 25.6 (C-20), 27.0 (C-6), 29.8 (C-11), 30.2 (C-7), 33.6 (C-4), 34.6 (C-10), 34.7 (C-8), 38.1 (C-16), 40.3 (C-5), 48.2 (C-9), 48.9 (C-14), 49.4 (C-13), 73.1 (C-12), 80.7 (C-1), 82.0 (C-17), 170.3 (C-3). See Figures S1-S4 in the Supplementary Materials for the MS and NMR spectra of compound 2.

\subsubsection{Transformation with Mortierella isabellina (Umbelopsis isabellina)}

The seven day transformation of oxandrolone (1) with M. isabellina AM212 resulted in a mycelial and broth extract, which was chromatographed on silica gel. Elution with methanol in chloroform yielded $9 \alpha$-hydroxyoxandrolone (3) (45 mg, 71\% mol.). Compound 3: amorphous solid, $[\alpha]_{\mathrm{D}}^{20}=-52\left(c 0.02, \mathrm{CHCl}_{3}\right)\left(\right.$ lit.: $\left.[\alpha]_{\mathrm{D}}^{25}=-55\left(c 0.0008, \mathrm{CHCl}_{3}\right)\right)$ [21].

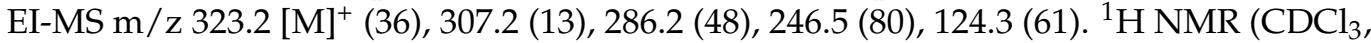
$600 \mathrm{MHz}) \delta$ (ppm): $0.89(\mathrm{~s}, 3 \mathrm{H}, 18-\mathrm{H}), 1.09(\mathrm{~s}, 3 \mathrm{H}, 19-\mathrm{H}), 1.21(\mathrm{~m}, 1 \mathrm{H}, 6 \beta-\mathrm{H}), 1.25(\mathrm{~s}, 3 \mathrm{H}$, 20-H), 1.30 (m, 1H, 11ß-H), $1.34(\mathrm{~m}, 1 \mathrm{H}, 15 \beta-\mathrm{H}), 1.41(\mathrm{~m}, 1 \mathrm{H}, 7 \beta-\mathrm{H}), 1.48(\mathrm{~m}, 1 \mathrm{H}, 15 \alpha-\mathrm{H})$, $1.53(\mathrm{~m}, 1 \mathrm{H}, 6 \alpha-\mathrm{H}), 1.55(\mathrm{~m}, 1 \mathrm{H}, 11 \alpha-\mathrm{H}), 1.58(\mathrm{~m}, 1 \mathrm{H}, 14-\mathrm{H}), 1.71(\mathrm{~m}, 2 \mathrm{H}, 12 \beta-\mathrm{H}, 16 \beta-\mathrm{H}$, $1.75(\mathrm{~m}, 2 \mathrm{H}, 8-\mathrm{H}, 12 \alpha-\mathrm{H}), 1.80(\mathrm{~m}, 1 \mathrm{H}, 16 \alpha-\mathrm{H}), 1.88(\mathrm{~m}, 1 \mathrm{H}, 7 \alpha-\mathrm{H}), 2.18(\mathrm{dd}, J=12.8 \mathrm{~Hz}$, $J=18.6 \mathrm{~Hz}, 1 \mathrm{H}, 4 \beta-\mathrm{H}), 2.45(\mathrm{~m}, 1 \mathrm{H}, 5-\mathrm{H}), 2.56(\mathrm{dd}, J=6.2 \mathrm{~Hz}, J=18.6 \mathrm{~Hz}, 1 \mathrm{H}, 4 \alpha-\mathrm{H}), 4.14$ $(\mathrm{d}, J=10.6 \mathrm{~Hz}, 1 \mathrm{H}, 1 \alpha-\mathrm{H}), 4.53(\mathrm{~d}, J=10.6 \mathrm{~Hz}, 1 \mathrm{H}, 1 \beta-\mathrm{H}) ;{ }^{13} \mathrm{C} \mathrm{NMR}\left(\mathrm{CDCl}_{3}, 151 \mathrm{MHz}\right) \delta$ (ppm): 11.9 (C-19), 13.0 (C-18), 23.0 (C-11), 24.2 (C-15), 26.0 (C-20), 27.0 (C-6), 27.1(C-12), 27.3 (C-7), 32.4 (C-5), 34.0 (C-4), 38.3 (C-8), 38.7 (C-16), 39.1 (C-10), 43.4 (C-14), 45.4 (C-13), 74.2 (C-9), 76.6 (C-1), 81.5 (C-17), 170.4 (C-3). See Figures S5-S7 for the MS and NMR spectra of compound 3 .

\subsubsection{Transformation with Laetiporus sulphureus}

The ten day transformation process of oxandrolone (1) with L. sulphureus AM498 resulted in a mycelial and broth extract, which was chromatographed on silica gel. Elution with methanol in chloroform yielded two metabolites: $6 \alpha$-hydroxyoxandrolone (4) (6 mg, 9\% mol.) and 15 $\alpha$-hydroxyoxandrolone (5) (44 mg, 70\% mol.). Compound 4 was as follows: resisted crystallization, $[\alpha]_{\mathrm{D}}^{20}=-57\left(c 0.02, \mathrm{CHCl}_{3}\right)\left(\right.$ lit.: $\left.[\alpha]_{\mathrm{D}}^{25}=-62.5\left(c 0.0008, \mathrm{CHCl}_{3}\right)\right)$ [21]; EI-MS m/z $323.2[\mathrm{M}]^{+}$(16), 307.2 (41), 286.3 (42), 246.5 (75), 79.3 (40). ${ }^{1} \mathrm{H} \mathrm{NMR}\left(\mathrm{CDCl}_{3}\right.$, $600 \mathrm{MHz}) \delta$ (ppm): $0.86(\mathrm{~m}, 1 \mathrm{H}, 9-\mathrm{H}), 0.87(\mathrm{~s}, 3 \mathrm{H}, 18-\mathrm{H}), 0.97(1 \mathrm{H}, \mathrm{m}, 7 \beta-\mathrm{H}), 1.02(\mathrm{~s}, 3 \mathrm{H}$, 
19-H), 1.22 (s, 3H, 20-H), 1.28 (m, 1H, 14-H), 1.31 (m, 1H, 15ß-H), $1.33(\mathrm{~m}, 1 \mathrm{H}, 12 \beta-\mathrm{H}), 1.39$ $(\mathrm{m}, 1 \mathrm{H}, 11 \alpha-\mathrm{H}), 1.44(\mathrm{~m}, 1 \mathrm{H}, 11 \alpha-\mathrm{H}), 1.55(\mathrm{~m}, 1 \mathrm{H}, 12 \alpha-\mathrm{H}), 1.61(\mathrm{~m}, 3 \mathrm{H}, 5-\mathrm{H}, 8-\mathrm{H}, 15 \alpha-\mathrm{H})$, $1.77(\mathrm{~m}, 1 \mathrm{H}, 16 \alpha-\mathrm{H}), 1.83(\mathrm{~m}, 1 \mathrm{H}, 16 \beta-\mathrm{H}), 2.05(\mathrm{dt}, J=4.1 \mathrm{~Hz}, J=12.3 \mathrm{~Hz}, 1 \mathrm{H}, 7 \beta-\mathrm{H}) ; 2.34$ $(\mathrm{dd}, J=12.7 \mathrm{~Hz}, J=19.0 \mathrm{~Hz}, 1 \mathrm{H}, 4 \beta-\mathrm{H}), 2.98(\mathrm{dd}, J=6.0 \mathrm{~Hz}, J=19.0 \mathrm{~Hz}, 1 \mathrm{H}, 4 \alpha-\mathrm{H}), 3.45-3.49$ $(\mathrm{m}, 6 \beta-\mathrm{H}), 3.93(\mathrm{~d}, J=10.7 \mathrm{~Hz}, 1 \mathrm{H}, 1 \alpha-\mathrm{H}), 4.21(\mathrm{~d}, J=10.7 \mathrm{~Hz}, 1 \mathrm{H}, 1 \beta-\mathrm{H}) ;{ }^{13} \mathrm{C} \mathrm{NMR}\left(\mathrm{CDCl}_{3}\right.$, $151 \mathrm{MHz}) \delta$ (ppm): 11.5 (C-19), 13.9 (C-18), 20.8 (C-11), 23.3 (C-15), 25.7 (C-20), 30.4 (C-4), 31.1 (C-12), 34.8 (C-8), 35.5 (C-10), 38.6 (C-16), 40.8 (C-7), 45.3 (C-13), 47.2 (C-5), 49.2 (C-9), 50.0 (C-14), 69.8 (C-6), 80.6 (C-1), 81.5 (C-17), 170.3 (C-3). See Figures S8-S11 for MS and NMR spectra of compound 4. (5): amorphous solid, $[\alpha]_{\mathrm{D}}^{20}=+39\left(c 0.02, \mathrm{CHCl}_{3}\right)$; EI-MS m/z $323.0[\mathrm{M}]^{+}(40), 307.2(17), 287.1(31), 246.3(60), 176.3$ (95). ${ }^{1} \mathrm{H}$ NMR and ${ }^{13} \mathrm{C}$ NMR data are shown in Table 2 and Figures S12-S17.

\section{Conclusions}

Here we reported the relative resistance of oxandrolone (1) to extensive transformations by the tested strains of fungi. The comparison of the transformation results between compound 1 and other steroidal substrates [9,12] indicated that the structure of the A ring of the steroid molecule significantly influences the position of the introduced hydroxyl group, making these processes highly regioselective. The obtained results extend our knowledge of the steroid-transforming activities of microbial fungi. The high substrate conversion rates and achieved product yields indicate that these strains may be promising biocatalysts in the synthesis of new bioactive steroids which might be of interest in academia and clinical medicine in the future.

Supplementary Materials: The following are available online at https: / www.mdpi.com/2073-4 344/11/1/16/s1, Figure S1: MS spectrum of 12 $\beta$-hydroxyoxandrolone (2), Figure S2: ${ }^{1} \mathrm{H}$ NMR spectrum of $12 \beta$-hydroxyoxandrolone (2), Figure S3: ${ }^{13} \mathrm{C}$ NMR spectrum of $12 \beta$-hydroxyoxandrolone (2), Figure S4: NOESY spectrum of $12 \beta$-hydroxyoxandrolone (2), Figure S5: MS spectrum of $9 \alpha-$ hydroxyoxandrolone (3), Figure S6: ${ }^{1} \mathrm{H}$ NMR spectrum of $9 \alpha$-hydroxyoxandrolone (3), Figure S7: ${ }^{13} \mathrm{C}$ NMR spectrum of $9 \alpha$-hydroxyoxandrolone (3), Figure S8: MS spectrum of $6 \alpha$-hydroxyoxandrolone (4), Figure S9: ${ }^{1} \mathrm{H}$ NMR spectrum of $6 \alpha$-hydroxyoxandrolone (4), Figure S10: ${ }^{13} \mathrm{C}$ NMR spectrum of $6 \alpha$-hydroxyoxandrolone (4), Figure S11: NOESY spectrum of $6 \alpha$-hydroxyoxandrolone (4), Figure S12: MS spectrum of $15 \alpha$-hydroxyoxandrolone (5), Figure S13: ${ }^{1} \mathrm{H}$ NMR spectrum of $15 \alpha$-hydroxyoxandrolone (5), Figure S14: ${ }^{13} \mathrm{C}$ NMR spectrum of $15 \alpha$-hydroxyoxandrolone (5), Figure S15: DEPT spectrum of $15 \alpha$-hydroxyoxandrolone (5), Figure S16: HSQC spectrum of $15 \alpha-$ hydroxyoxandrolone (5), Figure S17: NOESY spectrum of 15 $\alpha$-hydroxyoxandrolone (5).

Author Contributions: Conceptualization, A.Ś. and P.Ł.; methodology, P.Ł.; formal analysis, A.Ś.; P.Ł. and A.P.; investigation, P.Ł.; data curation, P.Ł.; writing—original draft preparation A.Ś., P.Ł. and A.P.; writing-review and editing, A.Ś. and A.P.; supervision, A.Ś.; project administration, P.Ł.; funding acquisition, P.Ł. and A.P. All authors have read and agreed to the published version of the manuscript.

Funding: This work was supported by the Wrocław University of Environmental and Life Sciences (Poland) as the Ph.D. research program "Innowacyjny Doktorat", no. N070/0011/20. Article Processing Charge (APC) was financed under the Leading Research Groups support project from the subsidy increased for the period $2020-2025$ by the amount of $2 \%$ of the subsidy referred to Art. 387 (3) of the Law of 20 July 2018 on Higher Education and Science, obtained in 2019.

Data Availability Statement: Data available in a publicly accessible repository.

Conflicts of Interest: The authors declare no conflict of interest.

\section{References}

1. Kristan, K.; Rižner, T.L. Steroid-transforming enzymes in fungi. J. Steroid Biochem. Mol. Biol. 2012, 129, 79-91. [CrossRef] [PubMed]

2. Świzdor, A.; Kołek, T.; Panek, A.; Milecka, N. Selective modifications of steroids performed by oxidative enzymes. Curr. Org. Chem. 2012, 16, 2551-2582. [CrossRef]

3. Sedlaczek, L.; Smith, L.L. Biotransformations of steroids. Crit. Rev. Biotechnol. 1988, 7, 187-236. [CrossRef] [PubMed] 
4. Hogg, J.A. Steroids, the steroid community, and Upjohn in perspective: A profile of innovation. Steroids 1992, 57, 593-616. [CrossRef]

5. Shull, G.M.; Kita, D.A. Microbiological conversion of steroids. I. Introduction of the $11 \beta$-hydroxyl group into $C_{21}$ steroids. J. Am. Chem. Soc. 1955, 77, 763-764. [CrossRef]

6. Świzdor, A.; Panek, A.; Milecka-Tronina, N. Hydroxylative activity of Aspergillus niger towards androst-4-ene and androst-5-ene steroids. Steroids 2017, 126, 101-106. [CrossRef]

7. Mishra, R.; Mishra, S. Updates in bile acid-bioactive molecule conjugates and their applications. Steroids 2020, $159,108639$. [CrossRef]

8. El Kihel, L. Oxidative metabolism of dehydroepiandrosterone (DHEA) and biologically active oxygenated metabolites of DHEA and epiandrosterone (EpiA)—Recent reports. Steroids 2012, 77, 10-26. [CrossRef]

9. Kołek, T.; Milecka, N.; Świzdor, A.; Panek, A.; Białońska, A. Hydroxylation of DHEA, androstenediol and epiandrosterone by Mortierella isabellina AM212. Evidence indicating that both constitutive and inducible hydroxylases catalyze $7 \alpha$ - as well as 7 $\beta$-hydroxylations of 5-ene substrates. Org. Biomol. Chem. 2011, 9, 5414-5422. [CrossRef]

10. Milecka-Tronina, N.; Kołek, T.; Świzdor, A.; Panek, A. Hydroxylation of DHEA and its analogues by Absidia coerulea AM93. Can an inducible microbial hydroxylase catalyze $7 \alpha$ - and $7 \beta$-hydroxylation of 5 -ene and $5 \alpha$-dihydro $\mathrm{C}_{19}$-steroids? Bioorg. Med. Chem. 2014, 22, 883-891. [CrossRef]

11. Meyer, W.; Gams, W. Delimination of Umbelopsis (Mucorales, Umbelopsidaceae fam. nov.) based on ITS sequence and RFLP data. Mycol. Res. 2003, 107, 339-350. [CrossRef] [PubMed]

12. Kołek, T.; Świzdor, A. Biotransformation XLV. Transformations of 4-ene-3-oxo steroids in Fusarium culmorum culture. J. Steroid Biochem. Mol. Biol. 1998, 67, 63-69. [CrossRef]

13. Kołek, T. Biotransformation XLVII: Transformations of 5-ene steroids in Fusarium culmorum culture. J. Steroid Biochem. Mol. Biol. 1999, 71, 83-90. [CrossRef]

14. Świzdor, A.; Kołek, T. Transformations of 4- and $17 \alpha$-substituted testosterone analogues by Fusarium Culmorum. Steroids 2005, 70, 817-824. [CrossRef] [PubMed]

15. Świzdor, A.; Kołek, T.; Szpineter, A. Transformations of steroid esters by Fusarium culmorum. Z. Nat. C 2006, 61, 809-814. [CrossRef]

16. Pappo, R.; Jung, C.J. 2-Oxasteroids: A new class of biologically active compounds. Tetrahedron Lett. 1962, 3, 365-371. [CrossRef]

17. Orr, R.; Singh, M.F. The anabolic androgenic steroid oxandrolone in the treatment of wasting and catabolic disorders: Review of efficacy and safety. Drugs 2004, 64, 725-750. [CrossRef]

18. Kratena, N.; Stöger, B.; Weil, M.; Enev, V.S.; Gärtner, P. Synthesis of two epimeric long-term metabolites of oxandrolone. Tetrahedron Lett. 2017, 58, 1316-1318. [CrossRef]

19. Foster, M.A.; Taylor, A.E.; Hill, N.E.; Bentley, C.; Bishop, J.; Gilligan, L.C.; Shaheen, F.; Bion, J.F.; Fallowfield, J.L.; Woods, D.R.; et al. Mapping the steroid response to major trauma from injury to recovery: A prospective cohort study. J. Clin. Endocrinol. Metab. 2020, 105, 925-937. [CrossRef]

20. Ring, J.; Heinelt, M.; Sharma, S.; Letourneau, S.; Jeschke, M.G. Oxandrolone in the treatment of burn injuries: A systematic review and meta-analysis. J. Burn. Care Res. 2020, 41, 190-199. [CrossRef]

21. Choudhary, M.I.; Mohammad, M.Y.; Musharraf, S.G.; Parvez, M.; Al-Aboudi, A.; Atta-ur-Rahman. New oxandrolone derivatives by biotransformation using Rhizopus stolonifer. Steroids 2009, 74, 1040-1044. [CrossRef] [PubMed]

22. Guddat, S.; Fußhöller, G.; Beuck, S.; Thomas, A.; Geyer, H.; Rydevik, A.; Bondesson, U.; Hedeland, M.; Lagojda, A.; Schänzer, W.; et al. Synthesis, characterization, and detection of new oxandrolone metabolites as long-term markers in sports drug testing. Anal. Bioanal. Chem. 2013, 405, 8285-8294. [CrossRef] [PubMed]

23. Rzeppa, S.; Viet, L. Analysis of sulfate metabolites of the doping agents oxandrolone and danazol using high performance liquid chromatography coupled to tandem mass spectrometry. J. Chromatogr. B 2016, 1029, 1-9. [CrossRef] [PubMed]

24. World Anti-Doping Agency Prohibited List. 2020. Available online: https://www.wada-ama.org/sites/default/files/wada_2020 _english_prohibited_list_0.pdf (accessed on 11 November 2020).

25. Massé, R.; Bi, H.; Ayotte, C.; Dugal, R. Studies on anabolic steroids II—gas chromatographic/mass spectrometric characterization of oxandrolone urinary metabolites in man. Biomed. Environ. Mass Spectrom. 1989, 18, 429-438. [CrossRef]

26. Desoky, E.-S.I.; Reyad, M.; Afsah, E.M.; Dawidar, A.-A.M. Synthesis and chemical reactions of the steroidal hormone $17 \alpha-$ methyltestosterone. Steroids 2016, 105, 68-95. [CrossRef] [PubMed]

27. Janeczko, T.; Popłoński, J.; Kozłowska, E.; Dymarska, M.; Huszcza, E.; Kostrzewa-Susłow, E. Application of $\alpha-$ and $\beta$ naphthoflavones as monooxygenase inhibitors of Absidia coerulea KCh 93, Syncephalastrum racemosum KCh 105 and Chaetomium sp. KCh 6651 in transformation of $17 \alpha$-methyltestosterone. Bioorg. Chem. 2018, 78, 178-184. [CrossRef]

28. Smith, C.; Atia-Tul-Wahab; Khan, M.S.A.; Ahmad, M.S.; Farran, D.; Choudhary, M.I.; Baydoun, E. Microbial transformation of oxandrolone with Macrophomina phaseolina and Cunninghamella blakesleeana. Steroids 2015, 102, 39-45. [CrossRef]

29. Świzdor, A.; Milecka, N.; Kołek, T.; Panek, A. Process for the Preparation of $3 \beta, 15 \alpha$-dihydroxy-5 $\alpha$-androst-17-one. Polish Patent PL 215785 B1, 31 January 2014. 